\title{
Effect of iron fortification on microstructural, textural, and sensory characteristics of caprine milk Cheddar cheeses under different storage treatments
}

\section{Aftab Siddique and Young W. Park*}

Georgia Small Ruminant Research and Extension Center, Fort Valley State University, The University System of Georgia, Fort Valley 31030

\section{ABSTRACT}

In this study, we manufactured 3 types of caprine milk Cheddar cheese: a control cheese (unfortified) and 2 iron-fortified cheeses, one of which used regular ferrous sulfate (RFS) and the other used large microencapsulated ferrous sulfate (LMFS). We then compared the iron recovery rates and the microstructural, textural, and sensory properties of the 3 cheeses under different storage conditions (temperature and duration). Compositional analysis included fat, protein, ash, and moisture contents. The RFS $\left(\mathrm{FeSO}_{4} \cdot 7 \mathrm{H}_{2} \mathrm{O}\right)$ and LMFS (with 700- to 800- $\mu \mathrm{m}$ large particle ferrous sulfate encapsulated in nonhydrogenated vegetable fat) were added to cheese curds after whey draining and were thoroughly mixed before hooping and pressing the cheese. Three batches of each type of goat cheese were stored at 2 temperatures $\left(4^{\circ} \mathrm{C}\right.$ and $\left.-18^{\circ} \mathrm{C}\right)$ for 0,2 , and 4 mo. We analyzed the microstructure of cheese using scanning electron microscopy and image analysis software. A sensory panel $(\mathrm{n}=8)$ evaluated flavors and overall acceptability of cheeses using a 10-point intensity score. Results showed that the control, RFS, and LMFS cheeses contained $0.0162,0.822$, and $0.932 \mathrm{mg}$ of $\mathrm{Fe} / \mathrm{g}$ of cheese, respectively, with substantially higher iron levels in both fortified cheeses. The iron recovery rates of RFS and LMFS were 71.9 and $73.5 \%$, respectively. Protein, fat, and ash contents (\%) of RFS and LMFS cheeses were higher than those of the control. Scanning electron microscopy analyses revealed that LMFS cheese contained smaller and more elongated sharp-edged iron particles, whereas RFS cheese had larger-perimeter rectangular iron crystals. Iron-fortified cheeses generally had higher hardness and gumminess scores than the control cheese. The higher hardness in iron-fortified cheeses compared with the control may be attributed to proteolysis of the protein matrix and

Received July 23, 2018.

Accepted December 9, 2018.

*Corresponding author: parky@fvsu.edu its binding with iron crystals during storage. Control cheese had higher sensory scores than the 2 iron-fortified cheeses, and LMFS cheese had the lowest scores for all tested sensory properties.

Key words: caprine cheese, iron fortification, microencapsulate, texture, sensory

\section{INTRODUCTION}

Iron deficiency anemia is a widespread epidemic around the world (Stockman, 1987; Zhang and Mahoney, 1989), and iron fortification in foods or iron supplements (Baltussen et al., 2004) have been recommended to remedy this global nutritional disorder. Iron fortification targets 2 major nutritional concerns of women and children - low birth weight and mental development of children (Zhang and Mahoney, 1989; Stoltzfus and Dreyfuss, 1998; Sugiarto, 2004).

Milk and dairy products represent one of the best vehicles for iron fortification in foods for human consumption (Allen et al., 2006). The quality of ironfortified milk and dairy products depends on the source and level of iron added. Iron fortification can elevate the average dietary intake of iron by 10 to $14 \%$ (Zhang and Mahoney, 1989). The latter authors found that the iron recovery rates from iron-fortified cheeses of different iron sources were 61 to $70 \%$ for $\mathrm{FeCl}_{3}, 52$ to $53 \%$ for ferric citrate, 55 to $57 \%$ for ferrous casein complex, and 70 to $75 \%$ for ferropolyphosphate-whey protein complex.

Iron fortification has significant effects on microstructural, textural, and sensory qualities of milk and dairy products. Structural specificity of a cheese is an important factor for its sensory properties and contributes to final product quality (Stanley, 1987; Langton et al., 1996). Use of scanning electron microscopy, confocal scanning laser microscopy, and transmission electron microscopy makes it possible to observe differences in the structure of cheeses affected by many factors, including species of milk, temperature treatment, rennet coagulation, ripening, and storage (Alichanidis and Polychroniadou, 2008; Rovira et al., 2011). Wide 
variations in microstructure within cheese texture can be expected (Pereira et al., 2001), because the number, shape, and size of pores vary depending on the aforementioned factors. The addition of other ingredients, such as iron salts, may cause further changes in the cheese texture because the added metals bind strongly with casein micelles, which would be in competition with calcium ions (Hegenauer et al., 1979).

The textural functionality of a cheese is influenced by several factors. Pastorino et al. (2003) found that lowering the $\mathrm{pH}$ from 5.3 to 5.0 of Cheddar cheese stored at $4^{\circ} \mathrm{C}$ for $40 \mathrm{~d}$ decreased the hardness, and similar results have been observed in other studies (Watkinson et al., 2001; Mangalika et al., 2005). A decrease in water activity due to evaporation of water, a change in $\mathrm{pH}$ due to proteolysis, and catabolism of lactic acid also affect the texture of cheese (Singh et al., 2003).

In a recent study of iron fortification in cow milk Cheddar cheeses, Arce and Ustunol (2018) found significant differences between iron-fortified and control cheeses in appearance and textural qualities. An untrained consumer panel scored the control (unfortified) cheese higher than the iron-fortified samples for appearance, texture, flavor, and overall acceptability. Microencapsulation failed to mask the distinct taste, color, and odor of iron. Small microencapsulated ferrous salt had higher scores for flavor and overall acceptability than large microencapsulated ferrous salt, indicating that addition of iron can alter the nutritional, textural, and sensory qualities of food products.

The effects of iron fortification on microstructural, textural, and sensory properties of bovine milk cheeses have been extensively reported, whereas such studies on caprine milk cheeses are almost nonexistent. Therefore, the objectives of our study were to (1) determine the effect of iron fortification on iron recovery in caprine milk Cheddar cheese; (2) examine microstructural specificities of control and iron-fortified cheeses, including iron foci and micrograph pore characteristics by scanning electron microscopy, and (3) compare textural and sensory characteristics of iron-fortified caprine cheeses with those of an unfortified control cheese under different storage treatments.

\section{MATERIALS AND METHODS}

\section{Experimental Design}

The study was conducted as a $3 \times 3 \times 2 \times 3$ factorial experiment. Three batches of caprine milk Cheddar cheeses were assigned to 3 iron fortification groups: unfortified control cheese (CC), fortification with regular ferrous sulfate (RFS), and fortification with large microencapsulated ferrous sulfate (LMFS). All cheese groups were divided into 2 halves, subjected to 2 temperature treatments $\left(4\right.$ and $\left.-18^{\circ} \mathrm{C}\right)$, and then stored for 3 storage periods of 0,2 , and 4 mo. At the end of each storage period, all experimental cheeses were evaluated in duplicate for nutrient contents, iron recovery, and microstructural, textural, and sensory properties.

\section{Manufacture of Experimental Caprine Milk Cheeses}

The caprine milk used in this study was taken from bulk tank milk that had been collected from the university milking goat herd (mainly the Alpine breed with some Toggenburg goats) during the mid-lactation period (June-July) at the Georgia Small Ruminant Research and Extension Center, Fort Valley State University (Fort Valley, GA).

Three batches each of CC, RFS, and LMFS goat milk Cheddar cheeses were manufactured using a modified procedure of Kosikowski and Mistry (1997) and Le Jaouen (1990). Each batch of cheese was made using between 135 and $170 \mathrm{~L}$ of milk maintained at $32^{\circ} \mathrm{C}$ in a $227-\mathrm{L}$ cheese vat. Lyophilized mesophilic direct vat set starter culture (R-704, Chr. Hansen Inc., Hørsholm, Denmark) and $18 \mathrm{~mL}$ of single-strength rennet (Chr. Hansen Inc.) were added to the milk, which was allowed to coagulate. The curd was cut using $1.6-\mathrm{cm}$ wire knives and the curds were slowly stirred. The cooking temperature of curds was raised gradually from $31^{\circ} \mathrm{C}$ to $39^{\circ} \mathrm{C}$ for $30 \mathrm{~min}$, the curd was cooked for an additional $15 \mathrm{~min}$, and then the whey was completely drained. The 2 divided chunk of curds in the cheese vat were turned over 3 times every $15 \mathrm{~min}$ for cheddaring and additional whey draining. For each batch of curds made, $0.8 \mathrm{~g}$ of RFS or $0.9 \mathrm{~g}$ of LMFS iron salts was added separately to $9 \mathrm{~kg}$ of fresh cheese curds in the rolling vacuum cylinder to achieve a homogeneous distribution of the iron salts in the cheese curds. After iron fortification and salting, curds were placed into $65 \times 255 \times 127 \mathrm{~mm}$ (width $\times$ length $\times$ height) stainless Wilson hoops and pressed at $275.8 \mathrm{kPa}$ (40 psi) overnight at room temperature in a vertical cheese press (Pneumatic Press, Kusel Equip. Co., Watertown, WI). Cheeses were removed from the hoops, cut into $7.62 \mathrm{~cm} \times 7.62 \mathrm{~cm}$ block size, and vacuum packaged in $10.16 \times 12.7 \mathrm{~cm}$ plastic pouches (FreshPak 500 vacuum pouches, Koch Supply, Kansas City, MO) using a vacuum packager (Koch Ultravac 250, Koch Supply), and then placed in the 2 temperature $\left(4\right.$ and $\left.-18^{\circ} \mathrm{C}\right)$ treatment groups.

\section{Fortification of Iron in Cheeses}

Because the net iron content of RFS $\left(\mathrm{FeSO}_{4} \cdot 7 \mathrm{H}_{2} \mathrm{O}\right)$ is $20 \%$ and that of LMFS is $16 \%, 0.80 \mathrm{~g}$ of food-grade RFS (Fisher Scientific) or $0.90 \mathrm{~g}$ of $700-$ to $800-\mu \mathrm{m}$ 
large particle nonhydrogenated fat microencapsulated ferrous sulfate (LMFS) salt (Dr. Paul Lohmann Inc., Islandia, NY) was added to the cheese curds after draining the whey and cheddaring process. Only $9 \mathrm{~kg}$ of cheese was used for iron fortification, and the 2 types of iron salts were added to the cheese curds before the salting step of cheese manufacture according to the modified method of Arce and Ustunol (2018). For the control cheese, only table salt was added $(0.25 \%$ of milk weight) to the curds without any iron fortification. All 3 treated groups (CC, RFS, and LMFS) of curds were thoroughly mixed after addition of the Fe salts, put into the stainless Wilson hoops, and pressed at 275.8 $\mathrm{kPa}$ (40 psi) overnight as described above.

\section{Chemical Analysis}

Moisture contents of the goat milk Cheddar cheese samples were determined in a laboratory drying oven at $105^{\circ} \mathrm{C}$ overnight using AOAC International (1995) method no. 926.10. The protein content of each type of goat Cheddar cheese samples was analyzed by using CEM Fastrac II analyzer (CEM Corporation, Matthews, NC) based on Kjeldahl method (AOAC International, 1995; method no. 955.04). The fat content of cheese samples was determined by the extraction and direct volatilization method of Folch et al. (1957). Ten grams of chloroform extract was placed in a clean, dry 25-mL Erlenmeyer flask and dried under the fume hood overnight to completely evaporate the solvent. The fat content of each sample flask was calculated by using the following equation:

Crude fat $(\%)=$

lipid weight $(\mathrm{g}) \times \frac{100 \mathrm{~mL} \text { of chloroform }}{10 \mathrm{~mL}} \times \frac{100 \%}{\text { sample weight }(\mathrm{g})}$.

Ash contents of all experimental goat milk cheeses were determined by AOAC International (1995) method no. 942.05. All cheese samples were dry ashed in a muffle furnace at $550^{\circ} \mathrm{C}$ for $8 \mathrm{~h}$ and cooled to room temperature in a desiccator to measure ash content.

Iron contents of experimental cheese samples were quantified by the Ferrozine (Acros Organics, Fair Lawn, NJ) colorimetric method (Zhang and Mahoney, 1989). The concentration of Ferrozine added to the final sample solution of each cheese sample was determined by observance at $562 \mathrm{~nm}$ using a UV-visible spectrophotometer (Evolution 201, Thermo Fisher Scientific, Madison, WI). Iron recoveries of the unknown samples were calculated according to the iron standard curve, which had 4 standards of Fe concentrations (5, 10, 25, and $50 \mathrm{mg}$ of $\mathrm{FeSO}_{4} / 100 \mathrm{~mL}$ of solution). The iron recovery rate was calculated according to the following equation:

Fe recovery $(\%)=$

$\underline{\text { Amt of } \mathrm{Fe} \text { in iron-added cheese }-\mathrm{Amt} \text { of } \mathrm{Fe} \text { in } \mathrm{CC}} \times 100 \%$. Amt of $\mathrm{Fe}$ in iron-added cheese

\section{Analysis of Cheese Microstructure and Identification of Iron Loci}

Cheese Fixation. Fixation of cheese samples was performed by a modified procedure of McManus et al. (1993), and images were captured using a variablepressure scanning electron microscope (model S-3400N II; Hitachi High Technologies America Inc., Pleasanton, CA). Four slices of $3 \times 3 \times 5 \mathrm{~mm}$ were cut vertically for each sample and rinsed with $0.1 M$ Sorensen's phosphate buffer ( $\mathrm{pH}$ 7.2; Electron Microscopy Sciences, Hatfield, PA) before and after primary fixing with $3 \%$ glutaraldehyde (Electron Microscopy Sciences) for 2 $\mathrm{h}$ and secondary fixing with $1.5 \%$ osmium tetraoxide (Electron Microscopy Sciences) for $1.5 \mathrm{~h}$. The fixed samples were dehydrated in a graded acetone (Sigma Aldrich, St. Louis, MO) series of 30, 40, 50, 70, 90, and $100 \%$ for 40 min each before critical point drying. The critical point drying was carried out using a Leica EM CPD 300 (Leica Mickrosysteme GmbH, Wein, Austria) automated critical point dryer in a specimen holder. After critical point drying, the samples were sputter coated (Desk V sputter coater, Denton Vacuum Desk $\mathrm{V}$, Moorestown, NJ) with a gold target for $60 \mathrm{~s}$ under a vacuum pressure of 0.05 Torr. The samples were photographed under the following conditions in the scanning electron microscope: accelerating voltage of $15 \mathrm{kV}$, emission current of $67,000 \mathrm{nA}$, and magnifications of $500 \times$ and $1,000 \times$.

Analysis of Cheese Micrographs. For computation of microstructure parameters, micrographs were analyzed using image analysis software (Image J, National Institutes of Health, Bethesda, MD). Different parameters related to pore microstructures - pore number observed from image surface, pore area (considering irregularities), and pore perimeter-were also analyzed. Micrographs were transformed into 8-bit 1,024 $\times 786$ pixel images and then normalized to maintain the original picture contrast.

Identification of Iron Loci in Cheese Microstructure. Identification and validation of iron crystals and their loci on the surface of the iron-fortified goat cheeses were conducted by comparison of scanning electron micrographs of iron-fortified RFS and LMFS cheeses and CC samples. Pore number, pore area, length of the 2 types of iron crystals, and pore perimeter in the microstructures of the experimental cheeses were 
analyzed using Image J software (National Institutes of Health).

\section{Texture Profile Analysis}

Textural characteristics of all cheese samples were determined by using a texture analyzer (TA-XT2; Texture Technologies Corp., Scarsdale, NY). A cylindrical alloy probe $2.5 \mathrm{~cm}$ in diameter and $3.5 \mathrm{~cm}$ in height was used to detect shear force (g). Samples of a suitable size were loaded on the analyzer with the probe speed set at $2 \mathrm{~mm} / \mathrm{s}$ (Guinard et al., 1997; Tunick, 2000). The basic properties of the texture profile included hardness, adhesiveness, resilience, cohesiveness, firmness, springiness, gumminess, and chewiness (Van Hekken et al., 2004; Park, 2007).

\section{Sensory Evaluation}

An 8-member trained sensory panel consisting of faculty and graduate students from College of Agriculture, Family Sciences and Technology at Fort Valley State University (Fort Valley, GA) evaluated the sensory properties of all treatment groups of caprine milk cheeses. All panelists were received preliminary training on goat cheese flavors and were provided with necessary instructions for the sensory tests. Panelists evaluated the flavor, body, texture, color, and appearance properties of the goat cheese products on a 10-point intensity scale according to the modified procedures of Judging and Scoring Milk and Cheese (USDA, 1975) and Alvarez et al. (2007), using the standard for ratings for all sensory descriptors. Panelists were also given instructions for descriptive languages, a flavor lexicon, and a scorecard for sensory scoring using the dairy goat products descriptive languages and lexicon of Carunchia Whetstine and Drake (2006). Cheese samples were $1.2 \times 1.5 \times 1.2 \mathrm{~cm}$, and samples were not tempered before being presented to panelists. Flavor parameters were scored by intensity (score 1-10) and evaluated for cooked, sweetness, freshness, rancid, whey, high acid, and oxidized properties.

\section{Statistical Analysis}

All experimental data collected in duplicate from all treated samples of the 3 batches of caprine milk cheeses were analyzed for ANOVA, least squares means, and effects of main factors and their interactions on nutritional, textural, and sensory characteristics using SAS software (version 9.4; SAS Institute Inc., 2013) and the Steel and Torrie (1960) method. A general linear model (GLM) was used to analyze the unbalanced data, and Duncan's multiple comparisons were used to separate the means.

\section{RESULTS AND DISCUSSION}

\section{Basic Nutrient Composition}

Significant differences $(P<0.05)$ were found in contents of ash, protein, fat, and moisture between control and iron-fortified cheeses (Table 1). Compared with CC, the RFS and LMFS cheeses had significant increases in protein, fat, and ash contents. Mean moisture content of CC (39.45\%) was higher than those of the iron-fortified cheeses (36.75 and $37.85 \%$ for RFS and LMFS, respectively). The composition (moisture, fat, and protein) of the control and iron-fortified goat milk cheeses of our study are in agreement with those of previous reports with cow and buffalo milk cheeses (El-Din et al., 2012; Indumathi et al., 2015).

Similar increases in ash, protein, and fat contents were observed in a study of cow milk Gouda cheese fortified with ferrous sulfate and whey protein-chelated iron salts (Indumathi et al., 2015). Buffalo Cheddar cheese stored at room temperature showed similar composition to cheeses in our study, although ash content (\%) was not affected by storage period from 0 to 3 mo (El-Din et al., 2012).

Table 1. Summary of basic nutrient compositions of fresh control and iron-fortified (RFS and LMFS) experimental goat milk Cheddar cheeses ${ }^{1}$

\begin{tabular}{|c|c|c|c|c|c|c|c|c|}
\hline \multirow[b]{2}{*}{ Item $^{2}$} & \multicolumn{2}{|c|}{ Ash (\%) } & \multicolumn{2}{|c|}{ Protein (\%) } & \multicolumn{2}{|c|}{ Fat $(\%)$} & \multicolumn{2}{|c|}{ Moisture (\%) } \\
\hline & Mean & $\mathrm{SD}$ & Mean & SD & Mean & $\mathrm{SD}$ & Mean & $\mathrm{SD}$ \\
\hline $\begin{array}{l}\text { Milk } \\
\text { Cheese }\end{array}$ & 0.79 & 0.06 & 3.1 & 0.05 & 3.56 & 0.07 & 87.95 & 1.28 \\
\hline $\mathrm{CC}$ & $3.52^{\mathrm{b}}$ & 0.12 & $28.01^{\mathrm{c}}$ & 0.08 & $27.81^{\mathrm{b}}$ & 0.98 & $39.45^{\mathrm{a}}$ & 0.67 \\
\hline RFS & $3.73^{\mathrm{ab}}$ & 0.15 & $34.47^{\mathrm{a}}$ & 0.91 & $30.18^{\mathrm{a}}$ & 0.96 & $37.65^{\mathrm{b}}$ & 0.52 \\
\hline LMFS & $3.97^{\mathrm{a}}$ & 0.16 & $33.09^{\mathrm{b}}$ & 0.97 & $29.83^{\mathrm{ab}}$ & 0.86 & $38.75^{\mathrm{ab}}$ & 0.64 \\
\hline
\end{tabular}

${ }^{\mathrm{a}-\mathrm{c}}$ Means with different superscripts within a column are significantly different $(P<0.05)$.

${ }^{1}$ All values are average of 3 batches of goat milk and cheeses in duplicate samples.

${ }^{2} \mathrm{CC}=$ control cheese (not fortified with iron); RFS $=$ cheese fortified with regular ferrous sulfate; LMFS = cheese fortified with large microencapsulated ferrous sulfate. 
Table 2. Comparison of iron concentrations and iron recovery rates of control and iron-fortified goat Cheddar cheeses $^{1}$

\begin{tabular}{lccccc}
\hline $\begin{array}{l}\text { Cheese } \\
\text { type }^{2}\end{array}$ & $\begin{array}{c}\text { Fe content in } \\
\text { cheese }(\mathrm{mg} / \mathrm{kg})\end{array}$ & $\begin{array}{c}\text { Fe added to } \\
\text { cheese }(\mathrm{mg})\end{array}$ & $\begin{array}{c}\text { Total Fe in } \\
\text { cheese }(\mathrm{mg})\end{array}$ & SD & $\begin{array}{c}\text { Fe recovery } \\
(\%)\end{array}$ \\
\hline CC & 0.0162 & 0.000 & $0.0162^{\mathrm{c}}$ & 0.021 & 0.00 \\
RFS & 0.0162 & 0.822 & $0.8382^{\mathrm{b}}$ & 0.014 & 71.9 \\
LMFS & 0.0162 & 0.932 & $0.9482^{\mathrm{a}}$ & 0.013 & 73.5 \\
\hline
\end{tabular}

${ }^{a-c}$ Means with different superscripts within a column are significantly different $(P<0.05)$.

${ }^{1}$ The Fe recovery rate was calculated using the method of Zhang and Mahoney (1989). See details in the Materials and Methods section.

${ }^{2} \mathrm{CC}=$ control cheese (not fortified with iron) RFS $=$ cheese fortified with regular ferrous sulfate; LMFS = cheese fortified with large microencapsulated ferrous sulfate.

The RFS and LMFS cheeses had higher levels of fat and protein than the unfortified CC. The increased fat and protein contents of RFS and LMFS may be related to the following physicochemical phenomena. In ruminants, milk is a poor source of iron and contains only 0.2 to $0.5 \mathrm{mg} / \mathrm{L}$ of milk. Of this small quantity, $14 \%$ of the iron is associated with the fat globule membrane. (Flynn and Cashman, 1997). Thus, iron in the milk fat may have contributed to the increased fat contents in the caprine cheeses. Caprine milk has more fat, protein and ash, and less lactose than bovine milk (Park, 2017), which could be associated with the higher protein and fat contents measured in iron-fortified goat cheeses (Table 1). Furthermore, vegetable oil encapsulation of the LMFS salt could increase the total fat content of iron-supplemented cheese samples (Arce and Ustunol, 2018). The larger size of the RFS iron crystal (Sklute et al., 2015) in the cheese protein matrix provides less space for escape of fat globule from the cheese matrix compared with the small, sharp iron crystals of LMFS, which could lead to less fat content compared with RFS cheeses. The addition of iron salts to the goat cheese may promote formation of further chemical structural bridges within casein networks, which could result in a more complex and rigid textural formation. This may lead to more fat entrapment in the cheese and a higher fat content in iron-fortified cheeses compared with control cheeses.

In terms of the increased protein contents of ironfortified caprine Cheddar cheeses, caseins, the major milk proteins, contain phosphorylated serine residues that serve as a major binding site for minerals, including added iron molecules. Clusters of phosphoserine residues are responsible for the high metal binding capacity of caseins, and develop a multi-dentate ligand property in which iron forms coordinate bonds between iron and the oxygen of the phosphorylated residue (Hegenauer et al., 1979; Bernos et al., 1997). Casein can bind more than $90 \%$ of the iron added to skim milk (Demott and Dincer, 1976). Thus, the added iron salts were likely bound to goat milk caseins in this study, which increased the extent of interactions or crosslink-

Table 3. Comparison of mean differences in microstructural parameters between control and 2 iron-fortified experimental goat milk Cheddar cheeses at 0,2 , and 4 mo of storage

\begin{tabular}{llrrr}
\hline Parameter & $\begin{array}{l}\text { Cheese } \\
\text { type }\end{array}$ & $\begin{array}{c}\text { Month 0 } \\
\text { (mean } \pm \text { SD) }\end{array}$ & $\begin{array}{c}\text { Month 2 } \\
(\text { mean } \pm \text { SD) }\end{array}$ & \multicolumn{1}{c}{$\begin{array}{c}\text { Month 4 } \\
(\text { mean } \pm \text { SD) }\end{array}$} \\
\hline Pore number $($ no. $)$ & CC & $163.32^{\mathrm{a}, \mathrm{y}} \pm 0.96$ & $134.56^{\mathrm{b}, \mathrm{y}} \pm 1.71$ & $113.52^{\mathrm{c}, \mathrm{z}} \pm 1.77$ \\
& RFS & $177.67^{\mathrm{a}, \mathrm{x}} \pm 0.12$ & $155.82^{\mathrm{b}, \mathrm{xy}} \pm 0.85$ & $146.65^{\mathrm{c}, \mathrm{y}} \pm 1.84$ \\
Pore area $\left(\mu \mathrm{m}^{2}\right)$ & LMFS & $179.43^{\mathrm{a}, \mathrm{x}} \pm 0.45$ & $157.60^{\mathrm{b}, \mathrm{x}} \pm 0.76$ & $149.94^{\mathrm{c}, \mathrm{x}} \pm 1.98$ \\
& CC & $323.45^{\mathrm{c}, \mathrm{y}} \pm 2.55$ & $362.67^{\mathrm{b}, \mathrm{z}} \pm 2.40$ & $590.67^{\mathrm{a}, \mathrm{y}} \pm 1.64$ \\
Length of iron crystal $(\mu \mathrm{m})$ & RFS & $343.76^{\mathrm{c}, \mathrm{y}} \pm 2.35$ & $553.65^{\mathrm{b}, \mathrm{x}} \pm 2.08$ & $686.56^{\mathrm{a}, \mathrm{x}} \pm 0.55$ \\
& LMFS & $416.34^{\mathrm{c}, \mathrm{x}} \pm 2.56$ & $449.89^{\mathrm{b}, \mathrm{y}} \pm 2.11$ & $691.78^{\mathrm{a}, \mathrm{x}} \pm 1.77$ \\
Pore perimeter $(\mu \mathrm{m})$ & CC & $0.00^{\mathrm{a}, \mathrm{y}} \pm 0.00$ & $0.00^{\mathrm{a}, \mathrm{z}} \pm 0.00$ & $0.00^{\mathrm{a}, \mathrm{z}} \pm 0.00$ \\
& RFS & $41.23^{\mathrm{c}, \mathrm{x}} \pm 2.66$ & $58.40^{\mathrm{b}, \mathrm{x}} \pm 1.91$ & $81.31^{\mathrm{a}, \mathrm{x}} \pm 1.39$ \\
& LMFS & $40.05^{\mathrm{c}, \mathrm{x}} \pm 5.09$ & $52.05^{\mathrm{b}, \mathrm{y}} \pm 1.90$ & $78.42^{\mathrm{a}, \mathrm{y}} \pm 1.88$ \\
& CC & $42.06^{\mathrm{c}, \mathrm{y}} \pm 0.12$ & $49.66^{\mathrm{b}, \mathrm{y}} \pm 0.05$ & $57.61^{\mathrm{a}, \mathrm{z}} \pm 0.15$ \\
& RFS & $51.87^{\mathrm{c}, \mathrm{xy}} \pm 0.14$ & $67.66^{\mathrm{b}, \mathrm{x}} \pm 0.05$ & $71.64^{\mathrm{a}, \mathrm{x}} \pm 0.03$ \\
& LMFS & $55.64^{\mathrm{c}, \mathrm{x}} \pm 0.24$ & $65.69^{\mathrm{b}, \mathrm{x}} \pm 0.13$ & $69.17^{\mathrm{a}, \mathrm{y}} \pm 0.07$ \\
\hline
\end{tabular}

${ }^{{ }^{\mathrm{a}} \mathrm{C}}$ Means with different superscripts within a row (between storage periods) are significantly different $(P<$ $0.05)$.

${ }^{\mathrm{x}-\mathrm{z}}$ Means with different superscripts within a column (between cheese types) are significantly different $(P<$ $0.05)$.

${ }^{1} \mathrm{CC}=$ control cheese (not fortified with iron); RFS $=$ cheese fortified with regular ferrous sulfate; LMFS $=$ cheese fortified with large microencapsulated ferrous sulfate. 

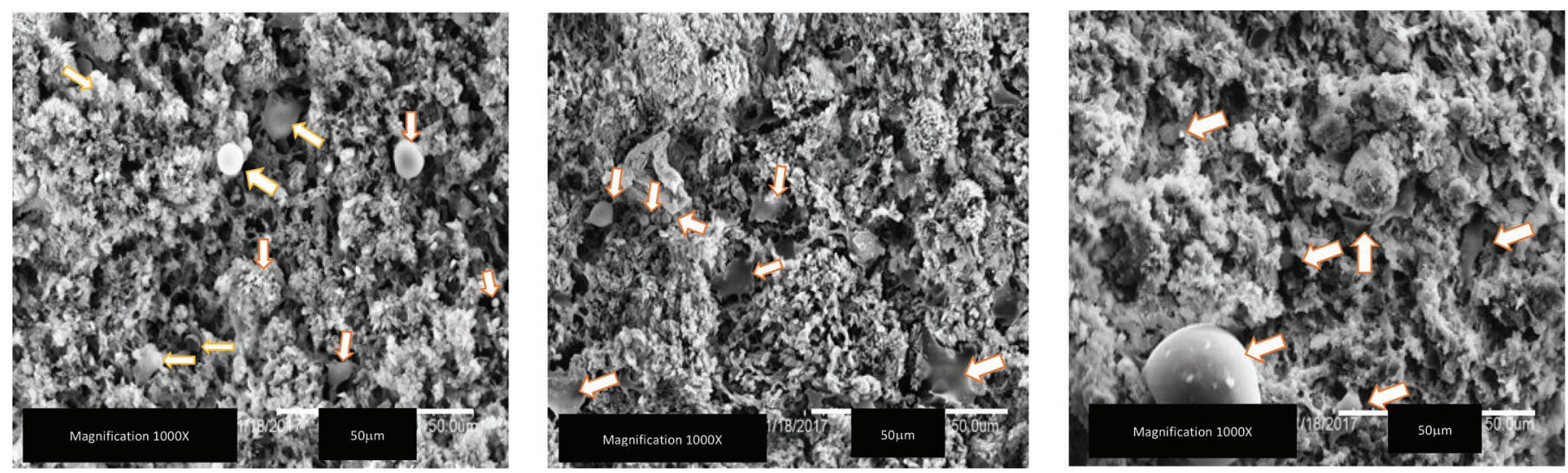

Figure 1. Comparison of scanning electron micrographs $(1,000 \times$; scale bar $=50 \mu \mathrm{m})$ of control (nonfortified) goat milk Cheddar cheeses stored at $4^{\circ} \mathrm{C}$ for 0,2 , and 4 mo of storage (from left to right, respectively). White arrows represent fat globules; dark/gray areas represent the protein network within the cheese matrix.

ing between proteins and iron salts, which could have increased the protein contents of the iron-fortified cheeses. Similarly, Kahraman and Ustunol (2012) observed that fortification of non-microencapsulated zinc sulfate in bovine Cheddar cheese resulted in higher protein and fat contents than in control cheese.

\section{Iron Recovery Rate from Iron-Fortified Caprine Cheeses}

The levels of iron addition and their recovery rates in the experimental cheeses are shown in Table 2. The iron recovery rates of RFS and LMFS salts in the experimental cheeses were 71.9 and $73.5 \%$, respectively, indicating that LMFS-fortified cheese retained more iron than the RFS-fortified cheese. This implies that microencapsulation may have prevented the loss of $\mathrm{Fe}$ molecules in the cheese curds during the pressing step of cheese manufacturing for further whey expulsion.
Previous reports on iron recovery rates of iron-supplemented bovine Cheddar cheeses showed 71 to $81 \%$ recovery for ferric chloride, 52 to $53 \%$ for ferric citrate, 55 to $72 \%$ for ferrous-casein complex (Zhang and Mahoney, 1989) $66.0 \%$ for LMFS, and $91.0 \%$ for small microencapsulated ferrous sulfate (SMFS)-fortified cheese (Arce and Ustunol, 2018). These data indicate that iron recovery of our LMFS cheeses was significantly higher than that of bovine milk Cheddar counterparts, whereas that of the SMFS-fortified bovine cheese (Arce and Ustunol, 2018) was significantly higher than that of caprine Cheddar cheeses with LMFS in the current study. It is not clear why the recovery rate of LMFS is higher in goat milk Cheddar cheese than that of the corresponding bovine counterpart in the previous study. However, a comparative study conducted by Slacanac et al. (2011) reported that levels of iron in natural non-iron-fortified white slice goat cheeses were significantly higher than those of corresponding cow
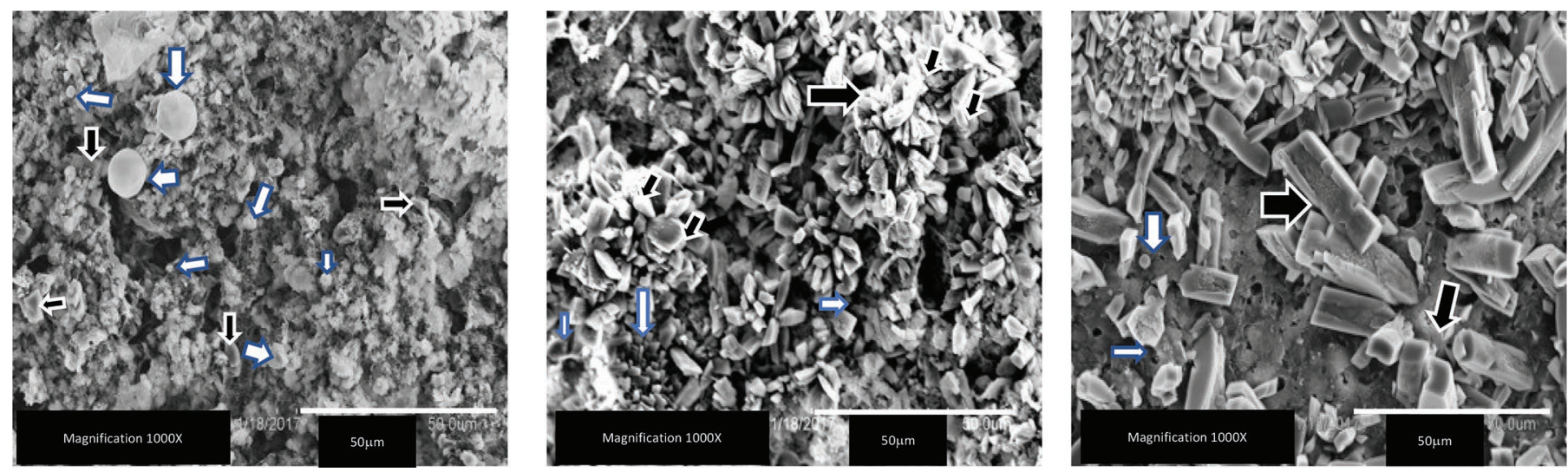

Figure 2. Comparison of scanning electron micrographs $(1,000 \times$; scale bar $=50 \mu \mathrm{m})$ of goat milk Cheddar cheeses fortified with regular ferrous sulfate (RFS cheeses) and stored at $4^{\circ} \mathrm{C}$ for 0,2 and 4 mo of storage (from left to right, respectively). White arrows represent fat globules; black arrows represent Fe crystals; dark/gray areas represent the protein network within the cheese matrix. 
milk cheeses produced from caprine and bovine milk herds in Croatia.

\section{Microstructure of Experimental Cheeses}

Microstructural parameters of the experimental cheeses among the 3 storage periods ( 0,2 , and $4 \mathrm{mo})$ were analyzed by scanning electron microscopy, and means and standard deviations of each parameter among cheese types and storage periods are compared in Table 3. In addition, changes in specific micrograph structures in CC, RFS and LMFS cheeses stored for 0, 2, and 4 mo are shown in Figures 1, 2, and 3.

All mean values of microstructural parameters of CC, RFS, and LMFS cheeses displayed clear trends of proteolytic changes in cheese protein matrix as storage time increased (Table 3). As storage time increased, pore numbers decreased as small pores merged to become large pores, and pore area and pore perimeter increased. The size of the iron crystals also increased with storage time (Table 3). Regardless of iron fortification, the proteolytic trends in microstructure of all cheeses were similar throughout storage. The control cheese had significantly fewer $(P<0.05)$ pores than the iron-fortified cheeses; LMFS cheeses had the greatest number of pores of the 3 cheeses. The opposite trend was observed for pore area, pore perimeter, and iron crystal length, where the average values of these parameters in LMFS cheeses were significantly lower $(P$ $<0.05)$ than those of RFS cheeses for most storage treatments (Table 3). However, we detected no difference between RFS and LMFS cheeses in pore perimeter at mo 2 , length of iron crystal at mo 0 , or pore area at mo 4. These results of changes in microstructural characteristics suggest that proteolysis of the cheese protein matrix in all experimental cheeses resulted in a decrease in pore numbers, whereas LMFS fortification increased pore perimeter and iron crystal size as storage time increased in goat milk Cheddar cheeses.

It has been reported that changes in structure of protein matrix, protein degradation, and protein microstructure can occur through proteolysis of cheese proteins during storage (Park, 2001; Soodam et al., 2017). The ripening of full-fat Cheddar cheese altered the pore size of cheese microstructure during $33 \mathrm{~d}$ of storage at $20^{\circ} \mathrm{C}$, and these structural changes were associated with increased proteolysis through solubilization of the protein network (Soodam et al., 2017). However, no significant differences were observed in microstructural changes in the goatskin bag cheese "Bouhezza" during 6 wk of storage at $-20^{\circ} \mathrm{C}$, when analyzed by scanning electron microscopy and confocal scanning electron microscopy (Zitoun et al., 2017).

Detailed micrographs of CC, RSF, and LMFS cheeses during the 4-mo storage period are shown in Figures 1, 2 , and 3 . The LMFS cheeses revealed more free cavities throughout the protein network, resulting in the highest average numbers of cheese surface pores compared with RFS and CC. In contrast, the highest pore areas were found in RFS cheeses, followed by LMFS and then $\mathrm{CC}$, indicating an inverse relationship between pore number and pore area. The larger pore area of RFS than in LMFS cheese may have been attributed to the hepta-hydrated water molecules in the natural state of regular $\mathrm{FeSO}_{4}$. In addition, larger irregular pore perimeters were observed in the RFS cheese compared with LMFS, and CC had significantly $(P<0.05)$ smaller pore perimeters than RFS cheese (Table 3 ).

The formation of the protein matrix of cheeses begins with the rearrangement of casein micelles, as demonstrated and analyzed by the method of Boutrou et al. (2002). These rearrangements of the protein network
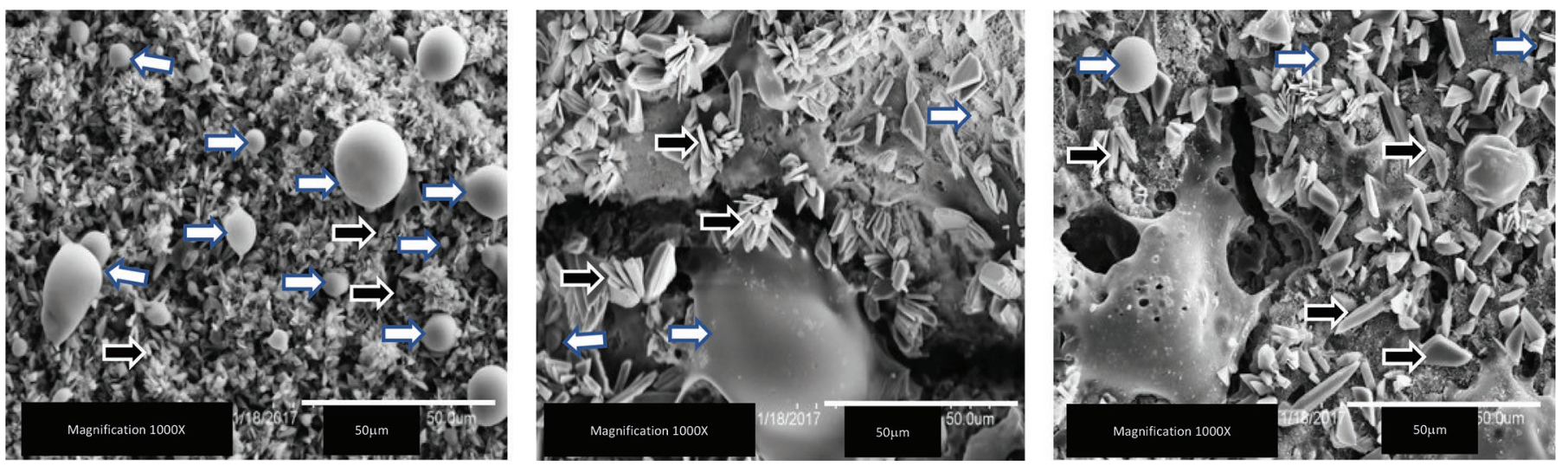

Figure 3. Comparison of scanning electron micrographs $(1,000 \times$; scale bar $=50 \mu \mathrm{m})$ of goat milk Cheddar cheeses fortified with large microencapsulated ferrous sulfate (LMFS cheeses) and stored at $4^{\circ} \mathrm{C}$ for 0,2 , and 4 mo of storage (from left to right, respectively). White arrows represent fat globules; black arrows represent Fe crystals; dark/gray areas represent the protein network within the cheese matrix. 
with changes in microstructural parameters indicated a clear trend of proteolysis in all 3 cheeses, as shown in Figures 1, 2 and 3. In addition, as storage time increased, the number of fat globules decreased in all cheeses (Figures 1,2 and 3), suggesting that lipolysis occurred as the storage period increased. This occurrence of significant lipolysis in goat milk cheeses has been reported in previous studies (Jin and Park, 1995; Park, 2001), where a concomitant effect of increased storage temperature and time greatly elevated lipolysis of different types of goat milk cheeses.

With respect to identification of iron loci in the 2 iron-fortified cheeses, the iron particles became more pronounced and visible as storage time increased in the RFS and LMFS cheeses, as shown in Figures 2 and 3. Figure 1 shows the micrograph for CC, which displayed no pronounced iron loci due to no addition of iron. The number of iron crystals in RFS and LMFS cheeses increased at 4 mo of storage, which might indicate that embedded iron in the fortified cheeses emerged from the cheese protein matrix and was more exposed from the proteolyzed protein networks of the microstructure of the aged cheeses. More calcium may have been dissolved and released from calcium caseinate due to the degraded protein network (Park, 2001; Soodam et al., 2017). In addition, this degradation could result in more competitive binding between $\mathrm{Ca}$ and $\mathrm{Fe}$ to caseinates of the cheeses, resulting in greater exposure of Fe particles in the microstructure of the aged cheeses.

The RFS cheeses contained longer iron crystals than LMFS cheeses. The iron crystals in the RFS cheeses were significantly $(P<0.05)$ longer than those in LMFS cheeses. Crystals of iron in RFS cheese samples were more rectangular and cuboidal in shape, as seen after 4 mo of storage (Figure 2). In contrast, LMFS cheeses contained clusters of iron salt where the iron crystals had sharp, pointed edges (Figure 3) and the iron particles were smaller and more elongated.

\section{Texture Profile Analysis}

Table 4 shows a statistical summary of textural properties of CC, RFS, and LMFS cheeses stored for 4 mo at $4^{\circ} \mathrm{C}$. A general trend was found for changes in these textural parameters. The hardness and gumminess values of all 3 cheeses showed a trend in which the values were high at 0 mo, decreased at 2 mo, and increased at 4 mo (Table 4; Figure 4a). This trend was observed for most of the other textural properties (Table 4; Figures $4 \mathrm{a}$ and $4 \mathrm{~b}$ ), except a few cases of textural parameters (scores for cohesion in LMFS, springiness in RFS and LMFS, gumminess in all 3 cheeses, and chewiness in LMFS). Figure 4 shows values of hardness and gumminess (panel 1) and resilience and springiness (panel b) as examples of the textural changes occurring during the storage period; results for all textural parameters are given in Table 4.

The decrease in hardness at 2 mo occurred because of proteolysis in the cheese matrix during storage, when the number of pores decreases because of breakage and fusion of the protein matrix and the texture softens. However, further proteolysis may result in more binding between the added iron crystals and the fused protein matrix, which could increase hardness again by 4 mo. The higher hardness in iron-fortified cheeses is also supported by previous reports. First, the complex casein structure forms with several crosslinking bonds between protein and iron crystals (Carmichael et al., 1975; Raouche et al., 2009). Due to the crosslinking and rigid structure, fat molecules present in cheese samples become entrapped in the cheese protein matrix, which increases the hardness of the structure. Second, the experimental iron salts serve as divalent metal impregnates between the casein molecules present in cheeses and fill the vacant spaces. These physicochemical changes in cheese protein matrix by proteolysis significantly $(P<0.01)$ affect cheese functionality and texture, as elucidated by Pastorino et al. (2003). Extra fat molecules from the encapsulation of the iron salts in the LMFS cheese may act as a source of filler molecules between the protein matrix. Kahraman and Ustunol (2012) found that fortification with nonencapsulated $\mathrm{Zn}$ had a similar effect of increasing the hardness of their bovine cheeses, where Fe and Zn have the same valence $(2+)$ for binding cheese proteins.

With regard to the effects of main factors and interactions on textural properties, cheese type had a significant effect $(P<0.05$ or $P<0.01)$ on all textural parameters except cohesion (Table 5). Batch and storage temperature did not affect any of the textural parameters, whereas storage period had significant effect on hardness $(P<0.01)$ and springiness $(P<0.05)$. For the interaction effects, a 2-way interaction effect was significant for cheese type $\times$ storage period on hardness $(P<0.01)$, springiness $(P<0.05)$, gumminess $(P<0.01)$, and chewiness $(P<0.01)$, indicating that changes in these textural traits did not show parallel increases with increasing storage time. The decrease and increase in textural traits (Table 4) also caused an apparent interaction effect in these textural values, which contributed to significant interaction effects, especially in the interaction between cheese type and storage period (Table 5). Other 2-way interaction effects were not significant (Table 5). For 3-way interaction effects, cheese type $\times$ storage temperature $\times$ storage period had significant $(P<0.01)$ influences on hardness, gumminess, and chewiness, and batch $\times$ storage period $\times$ storage time significantly $(P<0.05)$ affected cohesion. 
Table 4. Summary of mean textural parameters of 3 types of goat milk Cheddar cheeses stored at $4^{\circ} \mathrm{C}$ compared after 0,2 , and 4 mo of storage

\begin{tabular}{|c|c|c|c|c|}
\hline Textural parameter & Type $^{1}$ & $\begin{array}{c}\text { Month } 0 \\
(\text { mean } \pm \text { SD })\end{array}$ & $\begin{array}{c}\text { Month } 2 \\
(\text { mean } \pm \mathrm{SD})\end{array}$ & $\begin{array}{c}\text { Month } 4 \\
(\text { mean } \pm \mathrm{SD})\end{array}$ \\
\hline \multirow[t]{3}{*}{ Hardness } & $\mathrm{CC}$ & $5,363.9^{\mathrm{a}, \mathrm{x}} \pm 89.0$ & $4,134.8^{\mathrm{b}, \mathrm{y}} \pm 66.7$ & $5,313.5^{\mathrm{a}, \mathrm{x}} \pm 93.8$ \\
\hline & RFS & $5,117.7^{\mathrm{b}, \mathrm{x}} \pm 50.1$ & $4,755.9^{\mathrm{a}, \mathrm{z}} \pm 97.9$ & $5,001.5^{\mathrm{b}, \mathrm{y}} \pm 99.8$ \\
\hline & LMFS & $5.319 .1^{\mathrm{a}, \mathrm{x}} \pm 87.5$ & $4,857.1^{\mathrm{a}, \mathrm{y}} \pm 206.8$ & $5,346.4^{\mathrm{a}, \mathrm{x}} \pm 94.0$ \\
\hline \multirow[t]{3}{*}{ Adhesiveness } & $\mathrm{CC}$ & $-5.51^{\mathrm{a}, \mathrm{y}} \pm 2.55$ & $-3.62^{\mathrm{a}, \mathrm{x}} \pm 2.40$ & $-5.90^{\mathrm{b}, \mathrm{y}} \pm 1.64$ \\
\hline & RFS & $-5.43^{\mathrm{a}, \mathrm{y}} \pm 2.35$ & $-3.53^{\mathrm{a}, \mathrm{x}} \pm 2.08$ & $-4.86^{\mathrm{a}, \mathrm{y}} \pm 0.55$ \\
\hline & LMFS & $-5.16^{\mathrm{a}, \mathrm{x}} \pm 2.56$ & $-4.49^{\mathrm{a}, \mathrm{x}} \pm 2.11$ & $-4.91^{\mathrm{a}, \mathrm{x}} \pm 1.77$ \\
\hline \multirow[t]{3}{*}{ Resilience } & $\mathrm{CC}$ & $42.76^{\mathrm{a}, \mathrm{y}} \pm 2.60$ & $36.46^{\mathrm{b}, \mathrm{y}} \pm 2.72$ & $77.90^{\mathrm{a}, \mathrm{x}} \pm 1.25$ \\
\hline & RFS & $41.23^{\mathrm{a}, \mathrm{y}} \pm 2.66$ & $38.40^{\mathrm{a}, \mathrm{y}} \pm 1.91$ & $71.31^{\mathrm{b}, \mathrm{x}} \pm 1.39$ \\
\hline & LMFS & $25.05^{\mathrm{b}, \mathrm{y}} \pm 5.09$ & $25.05^{\mathrm{c}, y} \pm 5.90$ & $66.42^{\mathrm{c}, \mathrm{x}} \pm 1.88$ \\
\hline \multirow[t]{3}{*}{ Cohesion } & $\mathrm{CC}$ & $0.66^{\mathrm{a}, \mathrm{x}} \pm 0.12$ & $0.66^{\mathrm{b}, \mathrm{x}} \pm 0.05$ & $0.61^{\mathrm{a}, \mathrm{x}} \pm 0.15$ \\
\hline & RFS & $0.69^{\mathrm{a}, \mathrm{x}} \pm 0.04$ & $0.66^{\mathrm{b}, \mathrm{x}} \pm 0.05$ & $0.64^{\mathrm{a}, \mathrm{x}} \pm 0.07$ \\
\hline & LMFS & $0.64^{\mathrm{a}, \mathrm{xy}} \pm 0.04$ & $0.69^{\mathrm{a}, \mathrm{x}} \pm 0.13$ & $0.61^{\mathrm{a}, \mathrm{y}} \pm 0.07$ \\
\hline \multirow[t]{3}{*}{ Springiness } & $\mathrm{CC}$ & $84.97^{\mathrm{a}, \mathrm{y}} \pm 3.25$ & $78.19^{\mathrm{a}, \mathrm{z}} \pm 0.51$ & $87.78^{\mathrm{a}, \mathrm{x}} \pm 1.20$ \\
\hline & RFS & $75.99^{\mathrm{b}, \mathrm{z}} \pm 2.52$ & $78.35^{\mathrm{a}, \mathrm{y}} \pm 0.87$ & $86.84^{\mathrm{b}, \mathrm{x}} \pm 0.85$ \\
\hline & LMFS & $73.61^{\mathrm{c}, \mathrm{z}} \pm 1.15$ & $76.28^{\mathrm{b}, \mathrm{y}} \pm 1.48$ & $87.44^{\mathrm{a}, \mathrm{x}} \pm 0.76$ \\
\hline \multirow[t]{3}{*}{ Gumminess } & $\mathrm{CC}$ & $2,446.7^{\mathrm{b}, \mathrm{y}} \pm 43.1$ & $2,615.2^{\mathrm{b}, \mathrm{x}} \pm 32.1$ & $2,705.9^{\mathrm{b}, \mathrm{x}} \pm 56.0$ \\
\hline & RFS & $3,619.0^{\mathrm{a}, \mathrm{x}} \pm 39.6$ & $2,596.6^{\mathrm{b}, \mathrm{z}} \pm 31.6$ & $3,117.8^{\mathrm{a}, \mathrm{y}} \pm 52.0$ \\
\hline & LMFS & $2,701.8^{\mathrm{b}, \mathrm{y}} \pm 43.9$ & $3,481.8^{\mathrm{a}, \mathrm{x}} \pm 28.1$ & $3,275.1^{\mathrm{a}, \mathrm{x}} \pm 51.6$ \\
\hline \multirow[t]{3}{*}{ Chewiness } & $\mathrm{CC}$ & $3,609.9^{\mathrm{b}, \mathrm{x}} \pm 65.5$ & $3,408.5^{\mathrm{b}, \mathrm{z}} \pm 76.4$ & $3,509.2^{\mathrm{b}, \mathrm{y}} \pm 48.1$ \\
\hline & RFS & $4,604.7^{\mathrm{a}, \mathrm{x}} \pm 60.5$ & $3,445.5^{\mathrm{b}, \mathrm{z}} \pm 75.3$ & $3,996.0^{\mathrm{a}, \mathrm{y}} \pm 45.1$ \\
\hline & LMFS & $3,452.4^{\mathrm{b}, \mathrm{y}} \pm 65.2$ & $4,381.8^{\mathrm{a}, \mathrm{x}} \pm 70.1$ & $3,917.1^{\mathrm{a}, \mathrm{xy}} \pm 45.8$ \\
\hline
\end{tabular}

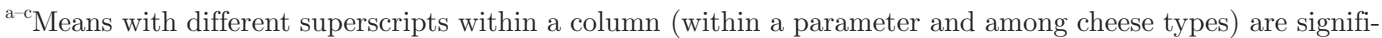
cantly different $(P<0.05)$.

${ }^{\mathrm{x}-\mathrm{z}}$ Means with different superscripts within a row (among storage periods) are significantly different $(P<0.05)$. ${ }^{1} \mathrm{CC}=$ control cheese (not fortified with iron); RFS $=$ cheese fortified with regular ferrous sulfate; LMFS = cheese fortified with large microencapsulated ferrous sulfate.

The outcomes of our study are comparable to the reports of Bontinis et al. (2008), in which the hardness of traditional Greek cheese manufactured from raw milk had the highest value ( 7 on the scale of $1-7$ ) over 180 d of storage. Kapoor et al. (2007) reported that saltto-moisture $(\mathbf{S} / \mathbf{M})$ ratio had significant effect on the chemical and functional properties of natural process cheese. In the present study, the $\mathrm{S} / \mathrm{M}$ ratios for RFS and LMFS cheeses were significantly $(P<0.05)$ higher than that of $\mathrm{CC}\left(5.83\right.$ and 5.82 vs. 5.45 at $4^{\circ} \mathrm{C}$ and 5.78 and 5.83 vs. 5.44 at $-18^{\circ} \mathrm{C}$, respectively in RFS, LFS, and CC). A higher S/M ratio value may indicate greater moisture drainage from cheese curds, resulting in higher hardness values in RFS and LMFS cheeses compared with CC cheeses.

\section{Sensory Properties}

The sensory evaluation scores on the 3 experimental cheeses are shown in Figure 5. Because there were many similarities in sensory scores, we compared pooled mean flavor scores (intensity scores 1-10) across all storage times and temperatures for 7 sensory properties of CC and the iron-fortified cheeses. The most pronounced observation was that LMFS cheese had the lowest sensory values in all tested sensory properties except for freshness, for which LMFS and RFS had similar scores, and oxidized flavor, for which LMFS scored numerically higher than RFS. These results may indicate that the LMFS salts added to the goat cheeses might have been less effective than expected in preventing the exposure of iron in the cheese lipids and protein network. In fact, oxidized flavors may develop from the presence of metal ions such as iron and copper in the cheese matrix during storage because of accelerated proteolysis and lipolysis (Park, 2001; Van Hekken et al., 2004; Sánchez-Macías et al., 2011). However, according to the manufacturer of the LMSF salt, microencapsulated iron can prevent lipid oxidation and mask the distinct flavor and odors of iron. Flavor scores for RFS cheese were similar to those for LMFS cheese, whereas CC had the highest sensory scores (Figure 5).

We detected significant differences $(P<0.05$ or 0.01$)$ in sensory scores for cooked, freshness, rancid, high acid, and oxidized flavors between the 2 iron-fortified cheeses and the control (Table 6); CC had the highest sensory values compared with RFS and LMFS (Table 6 ), which is in agreement with a recent study (Arce and Ustunol, 2018). That report showed that both SMFS and LMFS-fortified bovine Cheddar cheeses were scored lower $(P<0.05)$ than control bovine Cheddar cheese in appearance, texture, flavor, and overall acceptability.

In a study using LMFS and SMFS, Arce and Ustunol (2018) compared the sensory properties of ironfortified and control cow Cheddar cheeses, and found that iron fortification negatively affected cheese sensory 
attributes, particularly in LMFS-fortified cheese. They reported that microencapsulation of ferrous sulfate failed to mask iron's distinct taste, color, and odor. For overall sensory quality, SMFS showed better results than LMFS in terms of iron retention and sensory quality in bovine Cheddar cheese. The size of the microencapsulated particle was important in the retention of the iron in the cheese and its sensory attributes. They also noted that all treatments were significantly different $(P<0.05)$ in flavor and overall acceptability, and that the control cheese had the highest sensory score and LMFS-fortified cheese the lowest score, similar to the current results. We did not test SMFS fortification in our caprine cheese study because the US Food and Drug Administration recently banned the use of trans fats (partially hydrogenated fats) as a coating agent, and the manufacturer (Dr. Paul Lohmann Inc.) donated only nonhydrogenated LMFS (not SMFS) for our goat cheese study.

The ANOVA for effects of main factors and their interactions ( $F$-values) on sensory properties of the cheeses (Table 6) revealed that sensory characteristics
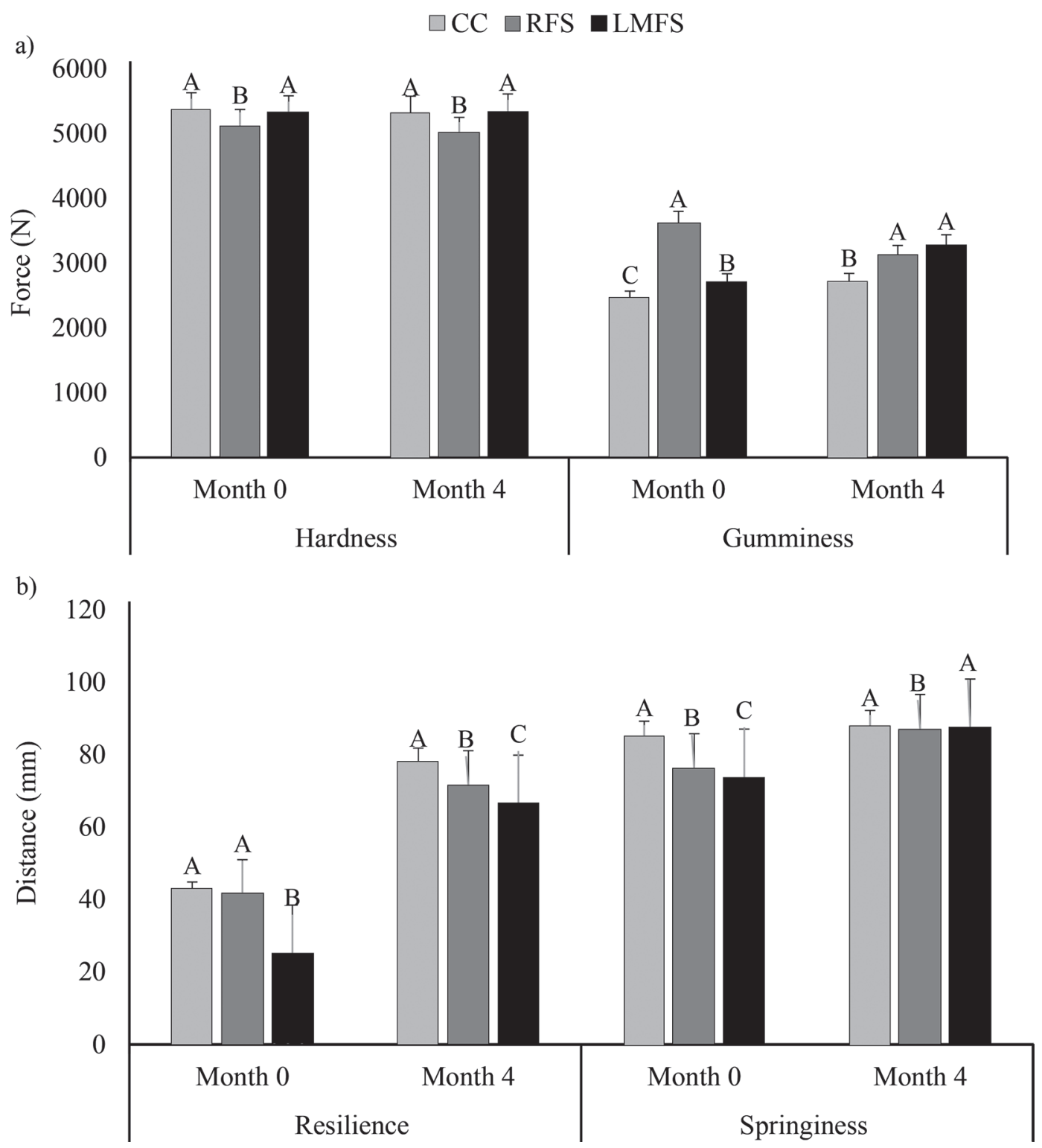

Figure 4. Mean hardness and gumminess values (a) and resilience and springiness values (b) of control (CC) and 2 iron-fortified goat Cheddar cheeses (RFS = cheese fortified with regular ferrous sulfate; LMFS = cheese fortified with large microencapsulated ferrous sulfate) after 0 and 4 mo of storage at $4^{\circ} \mathrm{C}$. Bars (means $\pm \mathrm{SD}$ ) with different letters (A, B, C) within a textural trait (panel a) or sensory trait (panel b) are significantly different $(P<0.05)$. 
Table 5. Analysis of variance ( $F$-values) on effects of main factors and their interactions on the change in textural properties of the experimental control cheese and iron-fortified goat milk cheeses after 4 mo of storage

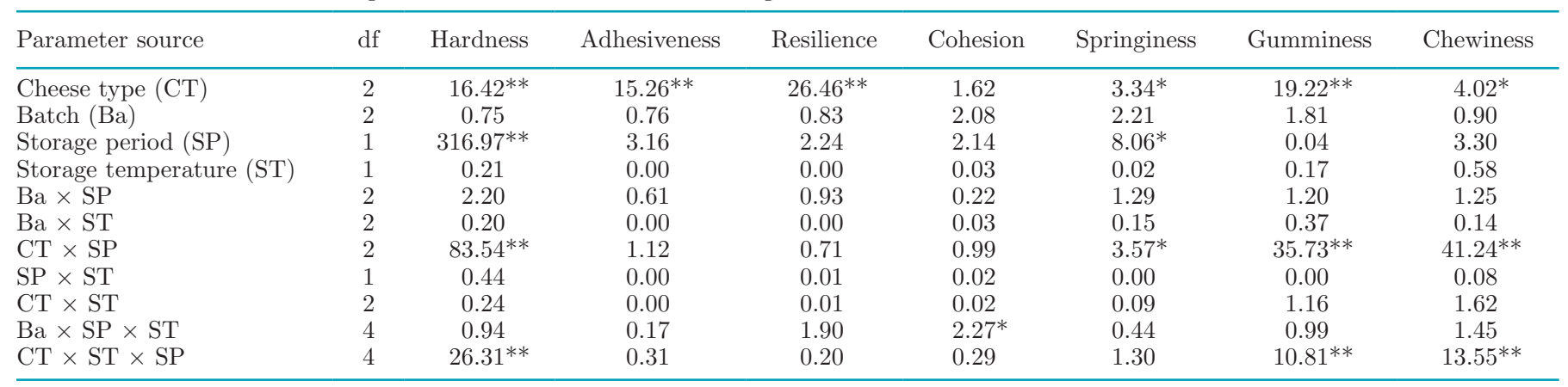

$* P<0.05 ; * * P<0.01$.

were significantly affected by cheese type $(P<0.05$ or $P<0.01)$, whereas only whey and oxidized flavors were affected $(P<0.05)$ by storage period. The sensory properties were not affected by 2 -way and 3 -way interactions between cheese type, storage temperature, and storage time (Table 6). The flavors of aged cheeses can be influenced by lipolysis and proteolysis of chesses during storage (Jin and Park, 1995; Park 2001; Van Hekken et al., 2005); rancid, high acid, and oxidized flavors in this study were influenced by cheese type (Figure 5; Table 6).

\section{CONCLUSIONS}

Iron fortification with RFS and LMFS salts increased fat and protein contents of goat milk Cheddar cheeses and increased hardness, chewiness, and gumminess compared with those of unfortified control cheeses. These results can be attributed to the formation of a complex protein network with an increased number of crosslinking bonds between proteins and iron crystals. Scanning electron microscopy was applied to calculate the number, area, and perimeter of pores and identified the iron loci of the 2 types of added iron crystals in the caprine cheeses. Iron fortification and storage time significantly affected the microstructural and tex- tural properties of caprine Cheddar cheeses. Sensory panel scores indicated that iron fortification negatively affected goat Cheddar cheese sensory attributes. Ironfortified cheeses, especially LMFS, consistently scored lower in flavor and acceptability for all tested sensory properties than the unfortified control cheese. Further studies are needed to assess effects of different forms (i.e., particle size) of iron microencapsulated with nonhydrogenated fat on changes in nutritional, textural, and sensory characteristics of caprine cheeses stored for longer storage periods, and to determine the mechanisms of increases in fat and protein contents in ironfortified caprine cheeses.

\section{ACKNOWLEDGMENTS}

The authors greatly appreciate Ralf Dieckhoff (Dr. Paul Lohmann Inc., Islandia, NY) for donation of the nonhydrogenated LMFS salt for our study. We also thank Brajesh N. Vaidya (Agricultural Research Station, Fort Valley State University, Fort Valley, GA) for his assistance in scanning electron microscopy laboratory procedures for sample preparation and micrographic analysis. This study was supported by the Agricultural Research Station project number USDA/GEOX-3225 of the USDA Evan-Allen Grant Funds. Mention of brand

Table 6. Analysis of variance ( $F$-values) for effects of main factors and their interactions on sensory properties of control and iron-fortified goat milk Cheddar cheeses under different storage treatments

\begin{tabular}{|c|c|c|c|c|c|c|c|c|}
\hline Parameter source & df & Cooked & Sweetness & Freshness & Rancid & Whey & High acid & Oxidized \\
\hline Storage temperature (ST) & 1 & 1.58 & 0.12 & 0.02 & 0.00 & 0.02 & 1.59 & 0.13 \\
\hline Storage period (SP) & 2 & 0.74 & 1.57 & 2.29 & 1.49 & $3.18^{*}$ & 2.38 & $3.33^{*}$ \\
\hline $\mathrm{CT} \times \mathrm{SP}$ & 4 & 0.11 & 0.05 & 0.04 & 0.75 & 0.12 & 0.16 & 0.23 \\
\hline $\mathrm{SP} \times \mathrm{ST}$ & 2 & 0.11 & 0.00 & 0.13 & 0.09 & 0.12 & 0.15 & 0.01 \\
\hline $\mathrm{CT} \times \mathrm{ST} \times \mathrm{SP}$ & 4 & 0.13 & 0.07 & 0.15 & 0.27 & 0.10 & 0.20 & 0.13 \\
\hline
\end{tabular}

${ }^{*} P<0.05 ;{ }^{* *} P<0.01$. 


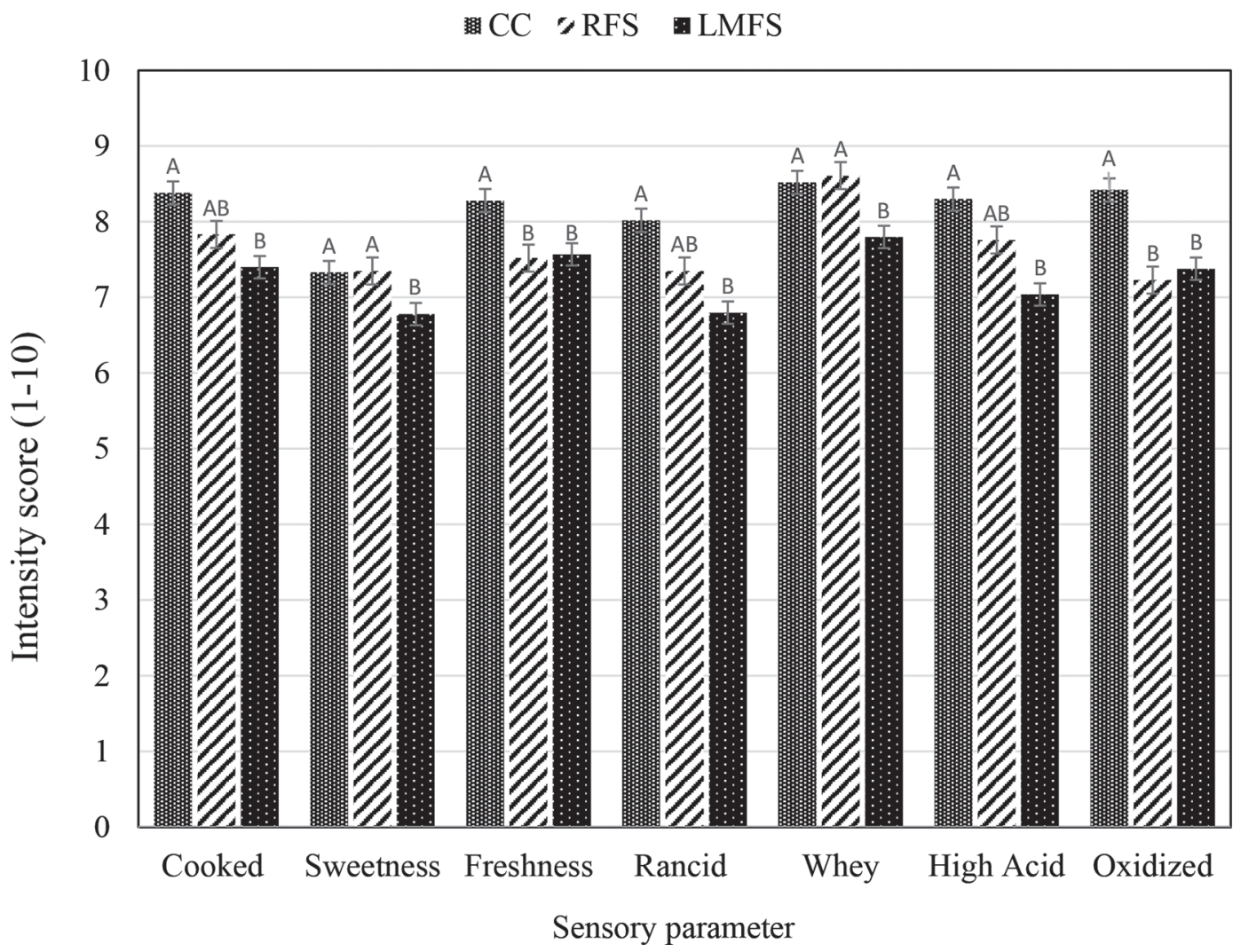

Figure 5. Overall mean flavor scores (intensity scores 1-10) of different sensory properties of control and 2 iron-fortified goat Cheddar cheeses (RFS $=$ cheese fortified with regular ferrous sulfate; LMFS = cheese fortified with large microencapsulated ferrous sulfate) across storage time and temperature treatments. Bars (means $\pm \mathrm{SD})$ with different letters $(\mathrm{A}, \mathrm{B})$ within a sensory parameter are significantly different $(P<0.05)$

names in this work does not constitute endorsement by Fort Valley State University or the USDA; other brands of equal functionality are equally suitable for the study.

\section{REFERENCES}

Alichanidis, E., and A. Polychroniadou. 2008. Characteristics of major traditional regional cheese varieties of East-Mediterranean countries: A review. Dairy Sci. Technol. 88:495-510. https://doi.org/ 10.1051/dst:2008023.

Allen, L. H., B. De Benoist, O. Dary, and R. Hurrell. 2006. Guidelines on food fortification with micronutrients. Accessed Jul. 28, 2017. http://apps.who.int/iris/bitstream/handle/10665/43412/ 9241594012_eng.df.

Alvarez, S., M. Fresno, P. Méndez, N. Castro, J. Fernandez, and M. Sanz Sampelayo. 2007. Alternatives for improving physical, chemical, and sensory characteristics of goat cheeses: The use of aridland forages in the diet. J. Dairy Sci. 90:2181-2188. https://doi .org/10.3168/jds.2006-506.

AOAC International. 1995. Official Methods of Analysis. 16th ed. AOAC International, Arlington, VA.

Arce, A., and Z. Ustunol. 2018. Effect of microencapsulated ferrous sulfate particle size on Cheddar cheese composition and quality. J. Dairy Sci. 101:6814-6822. https://doi.org/10.3168/jds.2017-13952

Baltussen, R., C. Knai, and M. Sharan. 2004. Iron fortification and iron supplementation are cost effective interventions to reduce iron deficiency in four subregions of the world. J. Nutr. 134:2678-2684. https://doi.org/10.1093/jn/134.10.2678.
Bernos, E., J. M. Girardet, G. Humbert, and G. Linden. 1997. Role of the O-phosphoserine clusters in the interaction of the bovine milk as1-, $\beta-, \kappa$-caseins and the PP3 component with immobilized iron (III) ions. Biochim. Biophys. Acta 1337:149-159. https://doi.org/ 10.1016/S0167-4838(96)00159-8.

Bontinis, T. G., H. Mallatou, E. Alichanidis, A. Kakouri, and J. Samelis. 2008. Physicochemical, microbiological and sensory changes during ripening and storage of Xinotyri, a traditional Greek cheese from raw goat's milk. Int. J. Dairy Technol. 61:229-236. https:// doi.org/10.1111/j.1471-0307.2008.00404.x.

Boutrou, R., M. H. Famelart, F. Gaucheron, Y. V. O. N. Le Graet, J. Y. Gassi, M. Piot, and J. Leonil. 2002. Structure development in a soft cheese curd model during manufacture in relation to its biochemical characteristics. J. Dairy Res. 69:605-618. https://doi .org/10.1017/S0022029902005836.

Carmichael, D., J. Christopher, J. Hegenauer, and P. Saltman. 1975. Effect of milk and casein on the absorption of supplemental iron in the mouse and chick. Am. J. Clin. Nutr. 28:487-493. https://doi .org/10.1093/ajcn/28.5.487.

Carunchia Whetstine, M. E., and M. A. Drake. 2006. Flavor characteristics of goat milk and other minor species milk products. Pages 107-120 in Handbook of Milk of Non-Bovine Mammals. Y. W. Park and G. F. W. Haenlein, ed. Blackwell Publishers, Ames, IA.

Demott, B. J., and B. Dincer. 1976. Binding added iron to various milk proteins. J. Dairy Sci. 59:1557-1559. https://doi.org/10.3168/jds .S0022-0302(76)84404-9.

El-Din, A. G., A. S. H. Hassan, S. A. El-Behairy, and E. A. Mohamed. 2012. Impact of zinc and iron salts fortification of buffalo's milk on the dairy product. World J. Dairy Food Sci. 7:21-27. https://doi .org/10.5829/idosi.wjdfs.2012.7.1.1102. 
Flynn, A., and K. Cashman. 1997. Nutritional aspects of minerals in bovine and human milks. Pages 257-302 in Advanced Dairy Chemistry. Vol. 3. Springer, Boston, MA. https://doi.org/10.1007/ 978-1-4757-4409-5_7.

Folch, J., M. Lees, and G. H. Sloane Stanley. 1957. A simple method for the isolation and purification of the total lipides from animal tissues. J. Biol. Chem. 226:497-509.

Guinard, J.-X., C. Zoumas-Morse, L. Mori, B. Uatoni, D. Panyam, and A. Kilara. 1997. Sugar and fat effects on sensory properties of ice cream. J. Food Sci. 62:1087-1094. https://doi.org/10.1111/j 1365-2621.1997.tb15044.x.

Hegenauer, J., P. Saltman, D. Ludwig, L. Ripley, and A. Ley. 1979. Iron-supplemented cow milk. Identification and spectral properties of iron bound to casein micelles. J. Agric. Food Chem. 27:12941301. https://doi.org/10.1021/jf60226a054.

Indumathi, K. P., R. Kaushik, S. Arora, and B. K. Wadhwa. 2015. Evaluation of iron fortified Gouda cheese for sensory and physicochemical attributes. J. Food Sci. Technol. 52:493-499. https://doi .org/10.1007/s13197-013-1006-y.

Jin, Y. K., and Y. W. Park. 1995. Effects of aging time and temperature on proteolysis of commercial goat milk cheeses produced in the United States. J. Dairy Sci. 78:2598-2608. https://doi.org/10 .3168/jds.S0022-0302(95)76888-6.

Kahraman, O., and Z. Ustunol. 2012. Effect of zinc fortification on Cheddar cheese quality. J. Dairy Sci. 95:2840-2847. https://doi .org/10.3168/jds.2011-4945.

Kapoor, R., L. E. Metzger, A. C. Biswas, and K. Muthukummarappan. 2007. Effect of natural cheese characteristics on process cheese properties. J. Dairy Sci. 90:1625-1634. https://doi.org/10 $.3168 /$ jds.2006-746.

Kosikowski, F. V., and V. V. Mistry. 1997. Cheddar cheese and related types. Pages 228-239 in Cheese and Fermented Milk Foods. Vol. 2. 2nd ed. F. V. Kosikowski LLC, AVI, Westport, CT.

Langton, M., A. Aström, and A. M. Hermansson. 1996. Texture as a reflection of microstructure. Food Qual. Prefer. 7:185-191. https:/ /doi.org/10.1016/S0950-3293(96)00030-4.

Le Jaouen, J. C. 1990. Pages 45-121 in The Making of Farmstead Goat Cheeses. Cheesemakers' Journal, Ashfield, MA.

Mangalika, U. L. P., S. Arora, G. S. Sharma, and V. Sharma. 2005. Lipolysis of coconut cream filled Gouda cheese during ripening. Indian Dairy Sci. Assoc. 58:90-95.

McManus, W. R., D. J. McMahon, and C. J. Oberg. 1993. Highresolution scanning electron microscopy of milk products: A new sample preparation procedure. Food Struct. 12:8.

Park, Y. W. 2001. Proteolysis and lipolysis of goat milk cheese. J Dairy Sci. 84(E. Suppl.):E84-E92. https://doi.org/10.3168/jds .S0022-0302(01)70202-0.

Park, Y. W. 2007. Rheological characteristics of goat and sheep milk. Small Rumin. Res. 68:73-87. https://doi.org/10.1016/j .smallrumres.2006.09.015.

Park, Y. W. 2017. Goat milk-Chemistry and nutrition. Pages 42-83 in Handbook of Milk of Non-Bovine Mammals. 2nd ed. Y. W. Park, G. F. W. Haenlein and W. L. Wendorff, ed. Wiley-Blackwell, Oxford, UK.

Pastorino, A. J., N. P. Ricks, C. L. Hansen, and D. J. McMahon. 2003. Effect of calcium and water injection on structure-function relationships of cheese. J. Dairy Sci. 86:105-113. https://doi.org/ 10.3168/jds.S0022-0302(03)73589-9.

Pereira, R. B., R. J. Bennett, Y. Hemar, and O. H. Campanella. 2001. Rheological and microstructural characteristics of model processed cheese analogues. J. Texture Stud. 32:349-373. https://doi.org/10 $.1111 / \mathrm{j} .1745-4603.2001 . t b 01242 . x$.

Raouche, S., M. Dobenesque, A. Bot, A. Lagaude, and S. Marchesseau. 2009. Casein micelles as a vehicle for iron fortification of foods. Eur. Food Res. Technol. 229:929-935. https://doi.org/10 .1007/s00217-009-1130-0.

Rovira, S., M. B. López, E. Ferrandini, and J. Laencina. 2011. Hot topic: microstructure quantification by scanning electron microscopy and image analysis of goat cheese curd. J. Dairy Sci. 94:10911097. https://doi.org/10.3168/jds.2010-3996.
Sánchez-Macías, D., A. Morales-delaNuez, I. Moreno-Indias, L. E. Hernández-Castellano, V. Mendoza-Grimón, N. Castro, and A. Argüello. 2011. Lipolysis and proteolysis profiles of fresh artisanal goat cheese made with raw milk with 3 different fat contents. J. Dairy Sci. 94:5786-5793. https://doi.org/10.3168/jds.2011-4423.

SAS Institute. 2013. Users Guide: SAS software, ver. 9.4. SAS Inst. Inc. Cary, NC.

Singh, T. K., M. A. Drake, and K. R. Cadwallader. 2003. Flavor of Cheddar cheese: A chemical and sensory perspective. Compr. Rev. Food Sci. Food Saf. 2:166-189. https://doi.org/10.1111/j.1541 $-4337.2003 . t b 00021 . x$.

Sklute, E. C., H. B. Jensen, A. D. Rogers, and R. J. Reeder. 2015. Morphological, structural, and spectral characteristics of amorphous iron sulfates. J. Geophys. Res. Planets 120:809-830.

Slacanac, V., J. Hardi, M. Lucan, D. K. Komlenic, V. Krstanovic, and M. Jukie. 2011. Concentration of nutritional important minerals in Croatian goat and cow milk and some dairy products made of these. Croat. J. Food Sci. Technol. 3:21-25.

Soodam, K., L. Ong, I. B. Powell, S. E. Kentish, and S. L. Gras. 2017. Effect of elevated temperature on the microstructure of full fat Cheddar cheese during ripening. Food Struct. 14:8-16. https://doi .org/10.1016/j.foostr.2017.05.003.

Stanley, D. W. 1987. Food texture and microstructure. Pages 35-64 in Food Texture: Instrumental and Sensory Measurement. H. R. Moskowitz, ed. Marcel Dekker Inc., New York, NY.

Steel, R. G. D., and J. Torrie. 1960. Principles and Procedures of Statistics. McGraw Hill Co., Inc., New York, NY.

Stockman, J. A. 1987. Iron deficiency anemia: Have we come far enough? JAMA 258:1645-1647. https://doi.org/10.1001/jama .1987.03400120095033.

Stoltzfus, R. J., and M. L. Dreyfuss. 1998. Guidelines for the use of iron supplements to prevent and treat iron deficiency anemia. Vol. 2. ILSI Press, Washington, DC. Accessed Jul. 26, 2017. https:/ /motherchildnutrition.org/nutrition-protection-promotion/pdf/ mcn-guidelines-for-iron-supplementation.pdf.

Sugiarto, M. W. 2004. Studies on the binding of iron and zinc to milk protein products. PhD Thesis. Riddet Centre and Institute of Food, Nutrition and Human Health, Massey University, New Zealand.

Tunick, M. H. 2000. Rheology of dairy foods that gel, stretch, and fracture. J. Dairy Sci. 83:1892-1898. https://doi.org/10.3168/jds .S0022-0302(00)75062-4.

USDA. 1975. Judging and scoring milk and cheese. USDA Farmers Bulletin No. 2259. Accessed Jul. 25, 2017. https://www.ams.usda .gov/sites/default/files/media/Judging\%20and\%20Scoring\%20 Milk\%20and\%20Cheese\%2C\%20Farmers\%27\%20Bulletin\%20No. $\% 202259 \% 2 \mathrm{C} \% 20$ USDA.pdf.

Van Hekken, D. L., M. H. Tunick, and Y. W. Park. 2004. Rheological and proteolytic properties Monterey Jack goat's milk cheese during aging. J. Agric. Food Chem. 52:5372-5377. https://doi.org/10 $.1021 /$ jf049918q.

Van Hekken, D. L., M. H. Tunick, and Y. W. Park. 2005. Effect of frozen storage on proteolytic and rheological properties of soft caprine milk cheese. J. Dairy Sci. 88:1966-1972. https://doi.org/10 .3168/jds.S0022-0302(05)72872-1.

Watkinson, P., C. Coker, R. Crawford, C. Dodds, K. Johnston, A. McKenna, and N. White. 2001. Effect of cheese $\mathrm{pH}$ and ripening time on model cheese textural properties and proteolysis. Int Dairy J. 11:455-464.

Zhang, D., and A. W. Mahoney. 1989. Effect of iron fortification on quality of cheddar cheese. J. Dairy Sci. 72:322-332. https://doi .org/10.3168/jds.S0022-0302(89)79113-X.

Zitoun, O. A., S. Carpino, N. Fucà, M. L. Mansour, H. Attia, and M. N. Zidoune. 2017. Microscopy of a goatskin bag cheese "Bouhezza". Pages 175-181 in Proc. 3rd Int. Multidisciplinary Microscopy and Microanalysis Congr. (InterM), Oludeniz, Turkey. Springer, Cham, Switzerland 